\title{
PENGOLAHAN LIMBAH KARET DENGAN FITOREMIDIASI MENGGUNAKAN TANAMAN Typha angustifolia
}

\author{
Syarif Nasrullah $^{1)}$ Rita Hayati ${ }^{2)}$ Ulli Kadaria ${ }^{1)}$ \\ ${ }^{1)}$ Program Studi Teknik Lingkungan Fakultas Teknik Universitas Tanjungpura, Pontianak \\ ${ }^{2)}$ Program Studi IImu Tanah Fakultas Pertanian Universitas Tanjungpura, Pontianak \\ Email : Syarifnasrullah@yahoo.com
}

\begin{abstract}
ABSTRAK
Limbah cair industri karet yang tidak diolah secara optimal dapat menjadi salah satu penyebab dari kerusakan lingkungan. Industri karet menghasilkan limbah cair dengan konsentrasi BOD $_{5} 508,47 \mathrm{mg} / \mathrm{l}$, COD 5009,5 mg/l dan TSS 806 mg/l. limbah tersebut telah melewati baku mutu. Menurut Peraturan Menteri Lingkungan Hidup No 5 tahun 2014, batas maksimum zat pencemar industri karet adalah $\mathrm{BOD}_{5} 100 \mathrm{mg} / \mathrm{l}, \mathrm{COD} 250 \mathrm{mg} / \mathrm{l}$ dan TSS $100 \mathrm{mg} / \mathrm{l}$. Oleh karena itu diperlukan pengolahan yang relatif murah dan cukup efisien. Pengolahan dengan Fitoremediasi menggunakan tanaman Typha angustifolia efektif dalam menurunkan kadar limbah dan tidak memerlukan biaya yang besar. Pengolahan yang dilakukan adalah dengan menggunakan lahan basah buatan yang di tanami dengan tanaman Typha angustifolia. Pengolahan ini bertujuan untuk mereduksi kadar BOD, COD, TSS dan pH. Pengolahan ini dilakukan dengan cara mengalirkan limbah karet kedalam reaktor selama 15 hari, kemudian dilakukan pengujian pada hari ke-9, hari ke-12 dan hari ke-15. Hasil pengujian menunjukan pengolahan dengan Fitoremidiasi menggunakan tanaman Typha angustifolia mampu menurunkan kadar BOD mencapai $90,00 \%$ dari 508,47 mg/L menjadi 53,32 mg/L. COD mencapai 90,15\% dari $5009,5 \mathrm{mg} / \mathrm{L}$ menjadi $493,3 \mathrm{mg} / \mathrm{L}$. TSS mencapai $94,42 \%$ dari $806 \mathrm{mg} / \mathrm{L}$ menjadi $45 \mathrm{mg} / \mathrm{L}$. pH mengalami peningkatan dari nilai awal 5,4 menjadi 6,1. Dari hasil penelitian menunjukan bahwa tanaman Typha angustifolia efektif dalam menurunkan kadar limbah karet.
\end{abstract}

Kata Kunci : Limbah Karet, Fitoremidiasi, Typha angustifolia, BOD, COD, TSS, pH

\section{ABSTRACT}

Rubber industrial liquid waste which cannot be processed optimally can be one of the causes of environmental damage. Rubber industries produce liquid waste with a concentration $508.47 \mathrm{mg} / \mathrm{l}$ BOD5, COD $5009.5 \mathrm{mg} / \mathrm{l}$ and TSS $806 \mathrm{mg} / \mathrm{l}$. raw sewage has passed the quality. According to the regulation of the Minister of the environment No 5 by 2014, the maximum limit of the substance rubber industrial polluters is $100 \mathrm{mg} / \mathrm{l}$ BOD5, COD $250 \mathrm{mg} / \mathrm{l}$ and $100 \mathrm{mg} / \mathrm{l} \mathrm{TSS}$. Therefore processing required is relatively inexpensive and quite efficient. Processing with Typha angustifolia plant using Fitoremediasi is effective in lowering the levels of waste and do not require a large fee. Processing is done is to use artificial wetlands in the Typha angustifolia plants. This treatment aims to reduce levels of BOD, COD, TSS and $\mathrm{pH}$. This processing is performed by means of rubber waste flow into the reactor for 15 days, then conducted testing on day 9, day 12 and day 15. The test results show the processing with Typha angustifolia plant using Fitoremidiasi is capable of lowering the levels of BOD reached $90.00 \%$ of $508.47 \mathrm{mg} / \mathrm{L}$ be $53.32 \mathrm{mg} / \mathrm{L}$ COD reach $90.15 \%$ of $5009.5 \mathrm{mg} / \mathrm{L}$ be $493.3 \mathrm{mg} / \mathrm{L}$ TSS. achieve $94.42 \%$ of $806 \mathrm{mg} / \mathrm{L}$ be $45 \mathrm{mg} / \mathrm{l}$. $\mathrm{pH}$ has increased from the initial value becomes 5.46 .1 . From the results of the study showed that the plant Typha angustifolia is effective in lowering the levels of waste rubber

Key words: Waste rubber, Phytoremediation, Typha angustifolia, BOD, COD, TSS, pH 


\section{PENDAHULUAN}

Industri pengolahan karet merupakan industri yang mengolah lateks (getah) karet menjadi karet setengah jadi. Hasil pengolahan karet berupa sit, krep, \& karet remah. Industri karet dalam pengolahannya menggunakan bahan-bahan kimia sebagai bahan koagulan lateks dan air dalam jumlah yang cukup besar untuk pencucian tangki-tangki tempat lateks serta untuk proses penggilingan. Limbah cair yang dihasilkan dari kegiatan tersebut adalah sebesar $400 \mathrm{~m}^{3}$ perhari, Limbah cair pabrik karet mengandung komponen karet (protein, lipid, karotenoid, dan garam anorganik), lateks yang tidak terkoagulasi dan bahan kimia yang ditambahkan selama pengolahan (Suwardin, 1989).

Menurut penelitian Sarengat (2015), industri karet menghasilkan limbah cair dengan konsentrasi BOD $_{5}$ 94-9433 mg/l, COD 120-15069 mg/l dan TSS 30-525 mg/l. Limbah cair tersebut jika dibuang ke lingkungnan akan mencemari lingkungan karena kandungan zat pencemar limbah cair karet berada diatas baku mutu. Menurut Peraturan Menteri Lingkungan Hidup No 5 tahun 2014, batas maksimum zat pencemar industri karet adalah $\mathrm{BOD}_{5} 100 \mathrm{mg} / \mathrm{l}, \mathrm{COD} 250 \mathrm{mg} / \mathrm{l}$, TSS $100 \mathrm{mg} / \mathrm{l}$ dan pH 6-9.

Limbah cair pabrik karet perlu dilakukan pengolahan terlebih dahulu untuk mencegah pencemaran. Pengolahan yang sedang berkembang saat ini adalah dengan menggunakan tanaman (fiotremidiasi), seperti tanaman Typha angustifolia. Menurut hasil penelitian Fitria (2013), tanaman Typha angustifolia mampu mereduksi limbah sawit yaitu kadar BOD dari $1900 \mathrm{mg} / \mathrm{l}$ menjadi $91 \mathrm{mg} / \mathrm{l}(95,21 \%)$, COD dari $2800 \mathrm{mg} / \mathrm{l}$ menjadi $242 \mathrm{mg} / \mathrm{l}$ (91,36\%) dan TSS dari 5400 mg/l menjadi 50,22 mg/l (99,07\%). Sejalan dengan Fitria (2013), Suwondo, dkk (2014) telah melakukan penelitian terhadap tanaman Typha angustifolia yang mampu mereduksi limbah sawit dengan kadar BOD dari $400 \mathrm{mg} / \mathrm{l}$ menjadi $14 \mathrm{mg} / \mathrm{l}$ (95,21\%) dan COD dari 8640 mg/l menjadi 576 mg/l (91,36\%). Hasil penelitian Evasari (2012) tanaman Typha angustifolia mampu mereduksi limbah cair domestik dengan kadar BOD $185 \mathrm{mg} / \mathrm{l}$ menjadi 18,5 mg/l (90\%), COD dari $488 \mathrm{mg} / \mathrm{l}$ menjadi 29,28 mg/l (90\%) dan TSS dari 498 $\mathrm{mg} / \mathrm{l}$ menjadi $49,80 \mathrm{mg} / \mathrm{l}(90 \%)$. Selain efektif dalam mereduksi limbah cair tanaman Typha angustifolia mempunyai daya tahan yang cukup kuat dan tidak mudah mati (Hidayah dan Wahyu, 2010).

\section{METODE PENELITIAN}

Penelitian ini dilaksanakan di Laboratorium Teknik Lingkungan Fakultas Teknik Universitas Tanjungpura dimulai.

Variabel yang digunakan dalam penelitian ini adalah variabel bebas dan terikat. Variabel bebas berupa waktu pengujian yaitu pada hari ke-9, hari ke-12 dan hari ke-15. Sedangkan variabel terikat adalah adalah penurunan angka limbah karet BOD, COD, TSS dan $\mathrm{pH}$

Pelaksanaan penelitian ini meliputi :

a. Persiapan Alat dan Bahan

Alat dan bahan yang digunakan dalam penelitian ini adalah limbah karet PT. Hok Tong Siantan, tanaman Typha angustifolia dengan berat $4 \mathrm{Kg} /$ Rumpun dan 2 buah bak reaktor batch berbahan kaca dengan ukuran $60 \mathrm{~cm} \times 30 \mathrm{~cm} \times 30 \mathrm{~cm}$, gate valve (stop kran) dan pipa 1 inci.

b. Perlakuan Awal

Perlakuan awal dalam penelitian ini adalah pembuatan 2 buah bak reaktor constructed wetland dengan model aliran surface wetland menggunakan tanaman Typha 
angustifolia. Pengambilan tanaman Typha angustifolia berdasarkan kriteria jumlah daun, batang, dan tinggi tanaman yang sama dengan berat $4 \mathrm{~kg}$. Selanjutnya akar tanaman Typha angustifolia dibersihkan dengan air.

\section{c. Aklimatisasi Tanaman}

Typha angustifolia yang digunakan untuk penelitian ini dipilih yang satu sama lain saling berdekatan. Setelah itu tanaman Typha angustifolia diseleksi, dicuci dengan air sumur sampai bersih untuk menghilangkan kotoran dalam akar tanaman. Tanaman diaklimatisasi dengan cara ditanam pada bak reaktor yang berisi tanah, pasir dan kerikil \pm selama 1 minggu. Tujuan pemeliharaan tanaman Typha angustifolia pada proses aklimatisasi untuk menstabilkan dan menyesuaikan keadaan lingkungan wetland untuk memulai proses biofilter (Muhajir, 2013)

d. Prosedur Penelitian

Sistem aliran yang digunakan dalam penelitian pengolahan limbah karet menggunakan tanaman Typha angustifolia adalah sistem aliran bawah permukaan (Sub Surface Flow Constructed Wetland). Bak reaktor dirancang dengan panjang $60 \mathrm{~cm}$, lebar 30 $\mathrm{cm}$ dan tinggi $30 \mathrm{~cm}$ (Hidayah dan Wahyu, 2010). Bak Reaktor diisi dengan tanaman Typha angustifolia dengan berat $4 \mathrm{~kg}$ dan jarak tiap tanaman $15 \mathrm{~cm}$. Pemilihan berat tanaman didasarkan pada penelitian Muhajir (2013). Sedangkan pemilihan jarak $15 \mathrm{~cm}$, berdasarkan dari penelitian Hidayah dan Wahyu (2010). Pada bak reaktor terdapat media tanam yang terdiri dari kerikil dan lumpur.

Selanjutnya, limbah industri karet dialirkan ke masing-masing bak reaktor constructed wetland dengan model aliran sub surface wetland. Limbah karet diuji kadar BOD, COD, TSS dan $\mathrm{pH}$ sebelum perlakuan. Pengujian limbah karet dilakukan terhadap variabel waktu detensi setelah 8 hari proses adaptasi tanaman dengan limbah, yaitu pada hari ke-9, hari ke12 dan hari ke-15 (Suwondo, dkk, 2014). Bak reaktor akan menampung limbah karet dengan volume 0,054 $\mathrm{m} 3$ atau 54 liter selama pengujian. Selama pengujian, bak reaktor limbah karet ditempatkan di halaman Laboratorium Teknik lingkungan Universitas Tanjungpura yang memiliki kanopi untuk mencegah masuknya air hujan, sehingga selama pengujian kualitas dan kuantitas limbah karet tetap terjaga.

Desain bak reaktor sistem aliran bawah permukaan dalam penelitian ini dapat dilihat pada gambar di bawah ini :

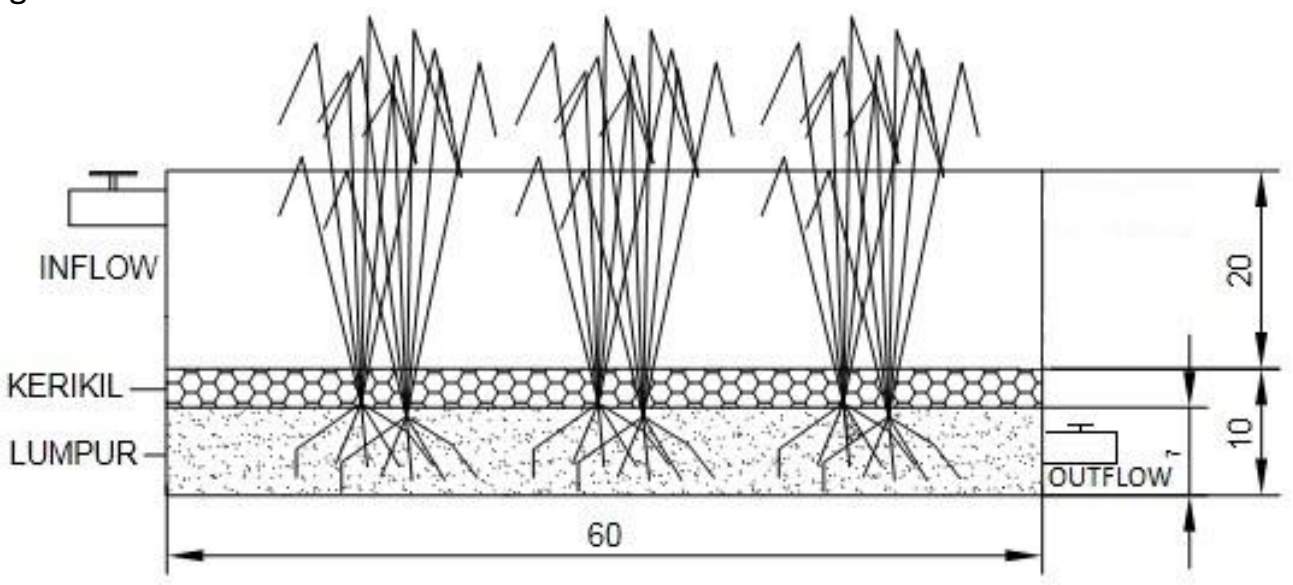

Gambar 1. Desain Bak Reaktor Tipe Aliran Bawah Permukaan 


\section{e. Analisa Data}

Fungsi kecepatan tanaman Typha angstifolia dalam mereduksi pencemar dalam limbah karet (BOD, COD, TSS, dan $\mathrm{pH}$ ) dapat diketahui setelah melakukan penelitian dan memperoleh data penelitian. Data akan diplot ke dalam sebuah grafik dan tabel hubungan waktu detensi terhadap persentase reduksi pencemar menggunakan Software Microsoft Excel. Dari grafik dan tabel yang diperoleh dapat di simpulkan fungsi kecepatan tanaman Typha angstifolia dalam mereduksi pencemar dalam limbah karet (BOD, COD, TSS, dan pH).

Efisiensi penyisihan zat pencemar dapat diketahui dari perhitungan persentase penyisihan zat pencemar dengan menggunakan rumus :

Dimana :

$$
\text { Efisiensi }(\%)=\frac{\mathrm{c} 1-\mathrm{c} 2}{c 1} \times 100 \%
$$

C1: Konsentrasi awal

C2 : konsentrasi akhir

\section{HASIL DAN PEMBAHASAN}

A. Kualitas Limbah Karet

Sebelum diberi perlakuan dengan metode wetland, limbah cair karet dianalisis BOD, COD, TSS dan pH untuk mengetahui kualitas dari limbah tersebut. Hasil pengujian kadar awal limbah karet kadar BOD, COD, TSS dan pH dapat dilihat dari Tabel 1.

Tabel 1. Kadar Awal Limbah karet

\begin{tabular}{cccc}
\hline Parameter & Satuan & Hasil Uji & Baku Mutu Air Limbah \\
\hline BOD & $\mathrm{mg} / \mathrm{L}$ & 508,47 & 100 \\
COD & $\mathrm{mg} / \mathrm{L}$ & 5009,5 & 250 \\
TSS & $\mathrm{mg} / \mathrm{L}$ & 806 & 100 \\
$\mathrm{pH}$ & - & 5,4 & $6,0-9,0$ \\
\hline
\end{tabular}

Berdasarkan Tabel 1, kualitas limbah karet tidak layak jika langsung di buang ke perairan karena nilai BOD, COD TSS dan pH berada di atas baku mutu, sesuai Peraturan Menteri Lingkungan Hidup No 5 tahun 2014, batas maksimum zat pencemar industri karet adalah BOD5 $100 \mathrm{mg} / \mathrm{l}$, COD $250 \mathrm{mg} / \mathrm{l}$, TSS $100 \mathrm{mg} / \mathrm{l}$ dan pH 6,0 - 9,0.

B. Limbah Karet Setelah Pengolahan dengan Tanaman Typha angustifolia.

- Penurunan BOD

Berdasarkan hasil pengujian kandungan BOD pada limbah Karet yang di olah menggunakan Tanaman Typha angustifolia pada lahan basah buatan (constructed wetland) selama 15 hari dapat dilihat pada Tabel 2. 
Tabel 2. Persentase Reduksi BOD pada Lahan Basah Buatan

\begin{tabular}{cccc}
\hline $\begin{array}{c}\text { Variasi Waktu } \\
\text { Pengujian }\end{array}$ & $\begin{array}{c}\text { Kondisi Awal } \\
(\mathrm{mg} / \mathrm{L})\end{array}$ & $\begin{array}{c}\text { Setelah } \\
\text { Pengolahan } \\
(\mathrm{mg} / \mathrm{L})\end{array}$ & $\begin{array}{c}\text { Persentse Reduksi } \\
(\%)\end{array}$ \\
\hline Hari Ke-9 & & 152,54 & 70,00 \\
Hari Ke-12 & 508,47 & 118,64 & 76,66 \\
Hari Ke-15 & & 50,84 & 90,00 \\
\hline
\end{tabular}

Tabel 2, menunjukan bahwa semakin lama waktu penanaman semakin besar penurunan kadar BOD. Semakin lama waktu kontak antara air limbah dengan biomassa maka proses degradasi bahan pencemar organik dapat berlangsung lebih lama sehingga kinerja reaktor akan semakin baik dan konsentrasi efluen yang dihasilkan juga semakin rendah. Beberapa hal yang dapat menjelaskan terjadinya penurunan bahan organik dalam SSF-Wetland tersebut, menurut Tangahu \& Warmadewanthi (2001) bahwa penurunan konsentrasi bahan organik dalam sistem wetlands terjadi karena adanya mekanisme aktivitas tanaman dan mikroorganisme. Akar tanaman Thypa angustifolia yang panjang dan lebat dapat menjangkau area yang lebih dalam dan luas sehingga dapat lebih banyak menyerap nutrien seperti phospat dan nitrogen dalam tanah serta mentransfer oksigen ke dalam dasar media dan memungkinkan mikroorganisme tumbuh di sekitar perakaran (zona rhizosphere). Menurut Handayanto dan Hairiah (2007), kondisi tanah di rizosfer sangat berbeda dengan kondisi tanah diluar rizosfer (non-rizosfer). Akar tanaman tidak saja berperan dalam penyerapan hara (baik melalui aliran massa, kontak langsung maupun difusi), tetapi juga sangat besar pengaruhnya terhadap perubahan kondisi rizosfer. Mikroorganisme tanah, seperti bakteri, jamur dan aktinomisetes lebih banyak dijumpai didaerah rizosfer daripada non-rizosfer. Dari ketiga jenis mikroorganisme tersebut, maka pengaruh rizosfer lebih besar pada bakteri, dengan nisbah populasi antara daerah rizosfer dibanding daerah non rizosfer $(\mathrm{R} / \mathrm{N})$ berkisar antara $10-20$ atau lebih. Menurut Haberl dan Langergraber (2002), bahwa proses fotosintetis pada tanaman air (hydrophyta), memungkinkan adanya pelepasan oksigen pada daerah sekitar perakaran (zona rhizosphere). Kondisi zona rhizosphere yang kaya akan oksigen, menyebabkan terjadinya perkembangan bakteri aerob di zona tersebut.

Menurut Metcalf \& Eddy (2003) karakteristik pertumbuhan bakteri, berdasarkan waktu ada 4 tahapan/fase pertumbuhan sebagaimana tersaji dalam gambar berikut ini : 


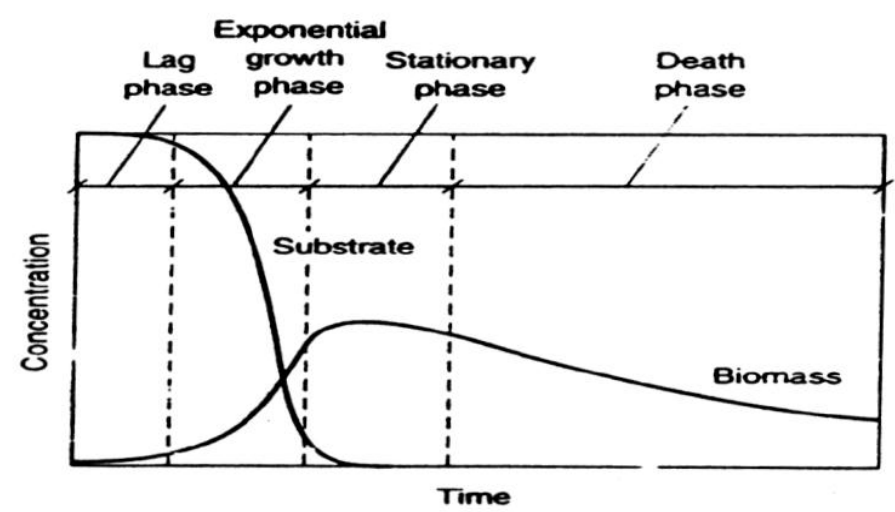

Gambar 2. Fase Pertumbuhan Bakteri

Berdasarkan hal tersebut diatas, maka peran utama mikroorganisme dalam mendegradasi bahan organik dalam sistem lahan basah buatan tersebut, akan dapat menjelaskan trend/kecenderungan penurunan bahan organik dari hasil percobaan. Adanya proses aklimatisasi tanaman pada awal percobaan, akan memberikan kesempatan pada bakteri yang terdapat rhizosphere untuk tumbuh dan beradaptasi, sehingga lag phase akan terjadi saat proses aklimatisasi tersebut. Dengan demikian maka pada awal penelitian, pertumbuhan bakteri telah mencapai fase pertumbuhan eksponensial (Exponential growth phase). Kondisi tersebut yang dapat menjelaskan bahwa penurunan BOD pada hari ke-9 penelitian terjadi penurunan yang tajam mencapai $70 \%$. Sedangkan hari pada hari-hari berikutnya sampai hari ke-15 penurunan hanya bertambah $20 \%$ dan bakteri diperkirakan telah memasuki fase bertahan (Stasionary Phase). Hari ke-15 nilai BOD limbah karet telah memenuhi baku mutu.

Pengolahan limbah karet dalam penelitian ini, berdasarkan tabel 2 persentase reduksi tertinggi terjadi pada hari ke 15 yaitu mencapai 90,00\% dengan nilai BOD 59,31 mg/L. Berdasarkan Peraturan Menteri Lingkungan Hidup No 5 tahun 2014, limbah karet parameter BOD telah mencapai baku mutu.

- Penurunan COD

Berdasarkan hasil pengujian kandungan COD pada limbah Karet yang di olah menggunakan Tanaman Typha angustifolia pada lahan basah buatan (constructed wetland) selama 15 hari dapat dilihat pada Tabel 3.

Tabel 3. Persentase Reduksi COD pada Lahan Basah Buatan

\begin{tabular}{cccc}
\hline $\begin{array}{c}\text { Variasi Waktu } \\
\text { Pengujian }\end{array}$ & $\begin{array}{c}\text { Kondisi Awal } \\
(\mathrm{mg} / \mathrm{L})\end{array}$ & $\begin{array}{c}\text { Setelah } \\
\text { Pengolahan } \\
(\mathrm{mg} / \mathrm{L})\end{array}$ & $\begin{array}{c}\text { Persentse Reduksi } \\
(\%)\end{array}$ \\
\hline Hari Ke-9 & & 4761,85 & 4,94 \\
Hari Ke-12 & 5009,5 & 1114,25 & 77,76 \\
Hari Ke-15 & & 493,3 & 90,15 \\
\hline
\end{tabular}


Berdasarkan Tabel 3, terjadi penurunan konsentrasi COD. Penurunan konsentrasi COD disebabkan adanya mekanisme aktivitas tanaman dan mikroorganisme. Mikroorganisme yang hidup dalam limbah cair karet akan mendapat suplay oksigen yang berasal dari tanaman di zona rhizosphere. Kondisi zona rhizosphere yang kaya oksigen, menyebabkan perkembangan bakteri aerob di zona tersebut semakin pesat. Sehingga dengan meningkatnya pertumbuhan mikroorganisme akan mempercepat proses penguraian konsentrasi COD. Fase pertumbuhan mikroorganisme terjadi saat awal-awal penelitian sampai hari ke 9. Hal ini dapat diketahui karena hari ke-9 penunrunan konsentrasi COD baru mencapai 4,94\%. Setelah hari ke-9 pertumbuhan mikroorganisme mencapai puncaknya dan penguraian bahan organik semakin besar, hal ini dapat dilihat pada hari ke-12 konsentrasi COD berkurang 77,76\% dengan nilai $1114.25 \mathrm{mg} / \mathrm{L}$ dan hari ke-15 konsentrasi COD berkurang sebesar 90,15\% dengan nilai $493,3 \mathrm{mg} / \mathrm{L}$. Reaksi yang terjadi pada proses penguraian bahan organik baik secara aerob maupun anaerob menurut Hammer (1986) adalah sebagai berikut :

$$
\begin{aligned}
& \text { Aerob : senyawa organik }+\mathrm{O}_{2} \longrightarrow \mathrm{CO}_{2}+\mathrm{H}_{2} \mathrm{O}+\mathrm{e} \\
& \text { Anaerob : senyawa organik }+\mathrm{NO}_{3^{-}} \longrightarrow \mathrm{CO}_{2}+\mathrm{N}_{2}+\mathrm{e}
\end{aligned}
$$

Berdasarkan tabel 3 penurunan konsentrasi COD semakin meningkat jika waktu waktu detensi semakin lama, Hal ini sejalan dengan pernyataan Evasari (2012) yang mengungkapkan bahwa semakin lama waktu detensi yang dibutuhkan bakteri maka reduksi COD dan BOD akan semakin tinggi.

Penurunan konsentrasi COD selain karena adanya aktivitas tanaman dan mikroorganisme, juga disebabkan karena adanya waktu detensi sehingga menyebabkan bahan padatan mulai mengendap sehingga bahan buangan di air limbah menjadi berkurang. Hal ini seperti yang di sampaikan Muhajir (2013) bawa penurunan nilai COD disebabkan karena bahan padatan telah mulai mengendap sehingga kandungan bahan organik di air limbah juga berkurang. Dari hasil pengujian menunjukan bahwa kadar COD mengalami penurunan yang cukup besar yaitu mencapai $90,30 \%$ dari kadar limbah awal sebesar 5009,5 $\mathrm{mg} / \mathrm{L}$ menjadi 493,3 mg/L pada hari ke-15. Tetapi nilai masih berada diatas baku mutu lingkungan sehingga limbah karet harus dilakukan pengolahan lanjutan.

Kadar COD yang masih melebihi baku mutu dapat diturunkan dengan pengolahan menggunakan reaktor biosand filter. Biosand filter merupakan pengembangan dari slow sand filter di mana biosand filter juga dapat menghilangkan bakteri patogen melalui proses yang sama dengan saringan pasir lambat, yaitu dengan cara melewati pasir dalam filter. Menurut penelitian Suligundi (2013) pengolahan limbah karet dengan reaktor biosand filter efektif dalam menurunkan konsentrasi COD. Dari hasil penelitiannya reaktor biosand filter mampu menurunkan konsentrasi COD mencapai 98,98\% dari kadar awal 1642,85 mg/L menjadi $34,09 \mathrm{mg} / \mathrm{L}$.

\section{- $\quad$ Penurunan TSS}

Berdasarkan hasil pengujian kandungan TSS pada limbah Karet yang di olah menggunakan Tanaman Typha angustifolia pada lahan basah buatan (constructed wetland) selama 15 hari dapat dilihat pada Tabel 4. 
Tabel 4. Persentase Reduksi TSS pada lahan basah buatan

\begin{tabular}{cccc}
\hline $\begin{array}{c}\text { Variasi Waktu } \\
\text { Pengujian }\end{array}$ & $\begin{array}{c}\text { Kondisi Awal } \\
(\mathrm{mg} / \mathrm{L})\end{array}$ & $\begin{array}{c}\text { Setelah } \\
\text { Pengolahan } \\
(\mathrm{mg} / \mathrm{L})\end{array}$ & $\begin{array}{c}\text { Persentse Reduksi } \\
(\%)\end{array}$ \\
\hline Hari Ke-9 & & 586,5 & 27,23 \\
Hari Ke-12 & 806 & 113 & 85,98 \\
Hari Ke-15 & & 45 & 94,42 \\
\hline
\end{tabular}

Tabel 4, menunjukan terjadinya penurunan konsentrasi TSS. Penurunan konsentrasi TSS disebabkan karena tanaman Thypa angustifolia memiliki akar serabut yang dapat menjadi tempat menempelnya koloid yang melayang di air. Semakin tinggi biomassa tanaman, semakin banyak akar serabutnya, maka semakin banyak koloid yang menempel di akar-akar tersebut. Endapan dan koloid serta bahan terlarut yang berasal dari bahan buangan yang berbentuk padat akan mengendap di dasar bila tidak dapat larut dan sebagian akan menjadi koloidal bila dapat larut. Endapan yang tidak dapat larut sebelum mencapai dasar akan melayang-layang dalam air bersama koloidial. Menurut Tangahu dan Warmadewanthi (2001) mekanisme filtrasi dan sedimentasi terjadi dalam sistem lahan basah buatan aliran bawah permukaan (SSF-Wetlands). Proses filtrasi dilakukan oleh akar tanaman yang terdapat dalam reaktor, dimana proses tersebut terjadi karena sistem perakaran membentuk filter yang dapat menahan partikel-partikel solid yang terdapat dalam air limbah, selain proses filtrasi terjadi juga proses sedimentasi, adanya waktu tinggal (detensi) limbah cair karet pada wetlands akan menyebabkan terjadinya proses sedimentasi pada partikel-partikel solid, sehingga material-material yang berasal dari bahan organik akan berkurang melalui proses sedimentasi.

- $\quad$ Peningkatan Nilai pH

Kondisi $\mathrm{pH}$ yang tidak netral menyulitkan proses biologis sehingga mengganggu proses penjernihannya (Sugiharto,1987). Bakteri pada umunya tumbuh dengan baik pada $\mathrm{pH}$ netral dan alkalis. Oleh karena itu proses dekomposisi bahan organik berlangsung lebih cepat pada kondisi netral dan alkalis. Limbah cair mempunyai $\mathrm{pH}$ asam yang menunjukan bahwa limbah tersebut mengandung asam-asam mineral atau asam organik yang tinggi. Selain itu megingat gas $\mathrm{CO}_{2}$ yang dihasilkan dari penguraian zat orgnik oleh mikroorganisme, maka setelah berdifusi dengan air akan terbentuk asam karbonat yang bersifat asam (Sunu, 2001). Dengan nilai $\mathrm{pH}$ yang cenderung asam ini diperlukan pengolahan agar nilai tersebut mencapai $\mathrm{pH}$ neral sesuai baku mutu limbah yang berlaku.

Hasil penelitian menunjukan limbah cair karet sebelum dilakukan pengolahan memiliki pH cenderung asam. Berikut ini adalah data $\mathrm{pH}$ limbah karet selama penelitian. 
Tabel 5. Kadar pH Limbah Karet Selama Pengujian

\begin{tabular}{ccc}
\hline Variasi Waktu Pengujian & Kondisi Awal pH & Setelah Pengolahan \\
\hline Hari Ke-9 & & 5,9 \\
Hari Ke-12 & 5,4 & 5,85 \\
Hari Ke-15 & & 6,1 \\
\hline
\end{tabular}

Berdasarkan tabel 5, terjadi peningkatan nilai $\mathrm{pH}$, sehingga pada pengolahan limbah karet hari ke-15 peningkatan $\mathrm{pH}$ telah mencapai baku mutu dengan nilai 6,1. Peningkatan nilai $\mathrm{pH}$ karena terjadinya proses degradasi bahan-bahan organik pada limbah karet, adanya tanaman Typha angustifolia menyebabkan terjadinya suplai okesigen ke dalam air limbah sehingga mempengaruhi proses degradasi bahan-bahan organik menjadi lebih cepat. Saat kadar bahan organik menurun, gas $\mathrm{CO}_{2}$ yang dihasilkan dari proses penguraian zat organik juga sedikit, sehingga asam karbonat yang berasal dari pendifusian $\mathrm{CO}_{2}$ dengan air akan berkurang. Berkurangnya asam karbonat menyebabkan terjadinya peningktatan nilai $\mathrm{pH}$. Hal ini sejalan dengan penelitian Muhajir (2013), mengenai pengolahan limbah tahu menggunakan tanaman Typha angustifolia. Hasil penelitiannya menunjukan terjadinya peningkatan nilai $\mathrm{pH}$. $\mathrm{pH}$ awal limbah tahu adalah 4,5 dan pada hari ke-20 penelitian $\mathrm{pH}$ naik menjadi 6,0. Standar baku mutu pH adalah 6,0-9,0, sehingga hasil penelitian ini menunjukan nilai $\mathrm{pH}$ telah memenuhi baku mutu.

\section{KESIMPULAN}

Berdasarkan hasil penelitian dan pembahasan yang telah dilakukan, maka dapat disimpulkan sebagai berikut :

1. Kadar konsentrasi limbah karet PT. Hok Tong, Siantan. Parameter Biological Oxygen Demand (BOD) 508,47 mg/L, Chemical Oxygen Demand (COD) 5009,5 mg/L, Total Suspended Solid (TSS) $806 \mathrm{mg} / \mathrm{L}$ dan $\mathrm{pH}$ 5,4.

2. Hasil penelitian menunjukan tanaman Typha angustifolia mampu mereduksi kandungan Biological Oxygen Demand (BOD) mencapai 90,00\% dari 508,47 mg/L menjadi $53,32 \mathrm{mg} / \mathrm{L}$. Chemical Oxygen Demand (COD) mengalami persentase penurunan 90,15\% dari 5009,5 mg/L menjadi 493,3 mg/L. Total Suspended Solid (TSS) mengalami persentase penurunan $94,42 \%$ dari $806 \mathrm{mg} / \mathrm{L}$ menjadi $45 \mathrm{mg} / \mathrm{L}$. pH mengalami peningkatan dari nilai awal 5,4 menjadi 6,1.

\section{UCAPAN TERIMA KASIH}

Terima kasih kepada Tim Dosen Skripsi saya (Ibu Rita Hayati, Ibu Ulli Kadaria, Ibu Isna Apriani dan Ibu Aini Sulastri), Community Development And Outreaching Universitas Tanjungpura, Program Studi Teknik Lingkungan, dosen dan staf Fakultas Teknik Universitas Tanjungpura, serta rekan-rekan yang membantu dalam pengerjaan penelitian ini.

\section{DAFTAR PUSTAKA}

Crites, R Dan Tchobanoglous, G. 1998. Small and Decentralizied Wastewater Management Ystems: Wetlends And Aquatic Treatment. Mcgraw-Gill Book. Co-Singapore

Evasari, J. 2012. Pemanfaatan Lahan Basah Buatan Dengan Menggunakan Tanaman Typha angustifolia Untuk Mengelola Limbah Cair Domestik. Universitas Indonesia, Jakarta. 
Fitria, L. 2013. Fitoremediasi Limbah Cair Kelapa Sawit Dengan Typha angustifolia Dalam Sistem Lahan Basah Buatan Sebagai Sumber Belajar Konsep Pencemaran Lingkungan Bagi Siswa Sma Kelas X. Universitas Riau. Pekanbaru.

Haberl, R., and Langergraber, H. 2002. Constructed wetlands: a chance to solve wastewater problems in developing countries. Wat. Sci. Technol. 40(17)

Hardayanto, E dan Hairiah, K. 2007. Biologi Tanah: Landasan Pengelolaan Tanah Sehat. Yogyakarta Pustaka Adipura.

Hidayah, E. N dan Aditia, W. 2010. Potensi Dan Pengaruh Tanaman Pada Pengolahan Air Limbah Domestik Dengan Sistem Constructed Wetland. Jurnal IImiah Teknik Lingkungan. 2(2).

Muhajir, M. S. 2013. Penurunan Limbah Cair Bod Dan Cod Pada Industri Tahu Menggunakan Tanaman Cattail (Typha Angustifolia) Dengan Sistem Constructed Wetland. Universitas Tanjung Pura, Pontianak.

Peraturan Menteri Lingkungan Hidup Republik Indonesia Nomor 5 Tahun 2014 tentang Baku Mutu Air Limbah.

Sarengat, N. 2015. Pengaruh Penggunaan Adsorben Terhadap Kandungan Amonia $\left(\mathrm{NH}_{3}-\mathrm{N}\right)$ Pada Limbah Cair Industri Karet Rss. Yogyakarta..

Suwardin, D. 1989. Teknik Pengendalian Limbah Pabrik Karet. Jurnal. Lateks Wadah Informasi dan Komunikasi Perkebun Karet. 4(2).

Suwondo, S. Wulandari dan Syaiful, A. 2014. Degradasi Limbah Cair Kelapa Sawit Dengan Penambahan Bakteri Rizosfir Actinomycetes Dan Tanaman Typha angustifolia Dengan Model Constructed Treatment Wetland (Ctw). Universitas Riau. Pekanbaru.

Suriawiria, Unus. 1993. Mikrobiologi Air. Bandung. Penerbit Alumni

Tangahu, B. V. dan Warmadewanthi, I. D. A. A. 2001. Pengelolaan Limbah Rumah Tangga Dengan Memanfaatkan Tanaman Cattail (Typha angustifolia) dalam Sistem Constructed Wetland. jurnal Purifikasi, 2(3), ITS, Surabaya. 